\section{Kidney \\ Blood Pressure Research}

\title{
Epinephrine Evokes Renalase Secretion via $\alpha$-Adrenoceptor/NF-kB Pathways in Renal Proximal Tubular Epithelial Cells
}

\author{
Feng Wang ${ }^{a}$ Hongyan Caib ${ }^{b}$ Qing Zhao ${ }^{c}$ Tao Xing ${ }^{d}$ Junhui Lia \\ Niansong Wang ${ }^{\text {a }}$
}

aDepartment of Nephrology and Rheumatology, Shanghai Jiao Tong University Affiliated Sixth People's Hospital, Shanghai 200233; ' Department of Microbiology and Immunology, Shanxi Medical University, Taiyuan 030001; 'Department of Cardiology, Shanghai Jiao Tong University Affiliated Sixth People's

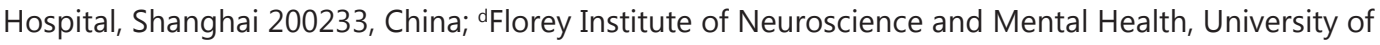
Melbourne, VIC 3010, Australia

\section{Key Words}

Renalase Epinephrine $\cdot$ Renal proximal tubular epithelial cell

\begin{abstract}
Background/Aims: Renalase is a recently discovered, kidney-specific monoamine oxidase that metabolizes circulating catecholamines. These findings present new insights into hypertension and chronic kidney diseases. Previous data demonstrated that renalase was mainly secreted from proximal tubules which could be evoked by catecholamines. The purpose of this study is to investigate whether renalase expression is induced by epinephrine via $\alpha$-adrenoceptor/ NFkB pathways. Methods: HK2 cells were utilized to explore renalase expression in response to epinephrine in vitro. Phentolamine, an $\alpha$-adrenoceptor antagonist, and Tosyl Phenylalanyl Chloromethyl Ketone (TPCK) were used to block $\alpha$-adrenoceptor and to knock down the transcription factor NFkB, respectively. Renalase expression was analyzed using Western blot and quantitative PCR. Results: Both protein and mRNA levels of renalase in HK2 cells increased in response to epinephrine $(P<0.05)$. Epinephrine-evoked renalase expression was attenuated by phentolamine and TPCK separately $(P<0.05)$. Conclusion: Epinephrine evokes renalase secretion via $\alpha$-adrenoceptor/NF-kB pathways in renal proximal tubular epithelial cells.
\end{abstract}

Drs. Hongyan Cai, Qing Zhao and Feng Wang contributed eaqually to this work.

Feng Wang, MD, PhD. 


\section{Kidney \\ Blood Pressure Research}

Kidney Blood Press Res 2014;39:252-259

\begin{tabular}{l|l}
\hline DOI: $10.1159 / 000355802$ & (C) 2014 S. Karger AG, Basel
\end{tabular}

Publisned ontrne: August 06, 2014

www.karger.com/kbr

Wang/Cai/Zhao/Xing/Li/Wang: Epinephrine Evokes Renalase via $\alpha$-Adrenoceptor/NFKB Pathways

\section{Introduction}

The kidney plays a vital role in the regulation of arterial blood pressure, but there are still many questions about how the kidney works in the development of hypertension and cardiorenal syndrome. Renalase, a newly discovered monoamine oxidase from the kidney, can metabolize circulatory catecholamines, which suggests novel mechanisms of cardiovascular complications in patients with chronic kidney diseases (CKD) [1]. Renalase is strongly expressed in the kidney and heart, and the kidney is the major source of blood renalase $[2,3]$.

Renalase decreases arterial blood pressure through oxidizing catecholamines (epinephrine $>>$ dopamine=norepinephrine), which is a new mechanism by which the kidney can regulate blood pressure [4]. Consistent with this new mechanism, CKD animal models demonstrate decreased renalase levels and increased catecholamine levels which are associated with elevated blood pressure [5]. Furthermore, a renalase knockout mouse presents moderate hypertension and a $\sim 3$ fold increase in plasma catecholamines [6]. Among the renal tissues, renalase expression is highest in the proximal tubules [1]. According to our previous results, renalase was not secreted by podocytes or mesangial cells but by proximial tubular epithelial cells in vitro [7].

Studies in the isolated perfused kidney model suggest that catecholamines stimulate renalase expression and secretion [8]. But how catecholamines enhance renalase secretion and which pathways participate in renalase expression is unknown. We hypothesize that epinephrine evokes renalase secretion via $\alpha$-adrenoceptor/NF- $\kappa B$ pathways in renal proximal tubular epithelial cells. This study on epinephrine-induced renalase expression in vitro was conducted to investigate the related pathways.

\section{Materials and Methods}

\section{Cell culture}

Human renal proximal tubular epithelial cells (HK2 cell line, ATCC) were cultured in Keratinocyte Serum Free Medium (K-SFM) (\#17005-042, GIBCO) and subcultured at 80\% confluence. To induce renalase expression, HK2 cells were incubated with epinephrine (E4642, Sigma-Adrith) $\left(10^{-8}, 10^{-7}, 10^{-6} \mathrm{~g} / \mathrm{L}\right)$ in 24 -well plates. Supernatants were used for Western blot analysis to determine secreted renalase levels. HK2 cells were collected to conduct total RNA extraction and quantitative real-time PCR was employed to determine the mRNA levels.

$\alpha$-adrenoceptor blocked with phentolamine in HK2 cells

In order to investigate whether epinephrine could induce renalase in HK2 cells through $\alpha$-adrenoceptor, HK2 cells were preconditioned for 30 min with phentolamine (P7547, Sigma-Aldrich) (1.0 $\mu \mathrm{mol} / \mathrm{L})$ before incubating with epinephrine $\left(10^{-7} \mathrm{~g} / \mathrm{L}\right)$. After treatment with epinephrine for $6 \mathrm{hr}$, HK2 cells were collected to extract total RNA. The changes of renalase mRNA were measured by quantitative PCR. After treatment with epinephrine for $24 \mathrm{hr}$, the supernatants of HK2 cells were prepared for Western blot analysis.

\section{NFKB inhibited with Tosyl Phenylalanyl Chloromethyl Ketone}

To investigate whether transcription factor $\mathrm{NF \kappa B}$ is involved in renalase expression, tosyl phenylalanyl chloromethyl ketone (TPCK) (T4376, Sigma-Aldrich) was used to inhibit NFKB activation. After preconditioning with TPCK for $30 \mathrm{~min}$, HK2 cells were stimulated with epinephrine $\left(10^{-7} \mathrm{~g} / \mathrm{L}\right)$ for 15 min and $6 \mathrm{hr}$, respectively. After $15 \mathrm{~min}$ the cells were harvested to determine the levels of Phospho-IкB $\alpha$ via Western blot. After $6 \mathrm{hr}$ the cells were harvested and total RNA was extracted for quantitative PCR to determine the mRNA levels of renalase.

\section{Western blot analysis}

Western blots were carried out according to what was described previously [7, 9, 10]. The protein sample concentrations were measured using the $\mathrm{ABC}$ kit. The primary antibodies were goat anti-renalase 


\section{Kidney \\ Blood Pressure Research}

Kidney Blood Press Res 2014;39:252-259

\begin{tabular}{l|l}
\hline DOI: $10.1159 / 000355802$ & (C) 2014 S. Karger AG, Basel
\end{tabular}

Publisned ontrne: August 06, 2014

www.karger.com/kbr

KB Pathways

polyclonal antibody (ab31291, Abcam) (1:500 dilution) and Phospho-IкB $\alpha$ (Ser32) (14D4) Rabbit mAb (\#2859, Cell Signaling) (1:500 dilution). All the data were obtained from ChemiDoc XRS+ System (BioRad) and band intensity was analyzed using Imag Lab 4.0.1 software.

Quantitative real-time PCR

Total RNA from HK2 cells was isolated using Trizol (Invitrogen). 18s rRNAs were used as internal normalizer control for mRNA. Levels of renalase mRNA in total RNA were quantified with one-step realtime PCR. Comparative Ct strategy was employed to process PCR results. The primers of renalase were 5'-GAAAAATCATTGCAGCCTCTCA-3' (foward) and 5'-AAGTTCTGCCTGTGCCTGTGTA-3' (reverse).

\section{Statitics}

Data were analyzed with SPSS 18.0 using a One-way ANOVA followed by Least Significant Difference (LSD) test. P values below 0.05 were considered significant.

\section{Results}

Epinephrine induced renalase expression

Compared to controls, the renalase protein levels increased significantly at $24 \mathrm{hr}$ in the supernatant of HK2 cells incubated with three different concentrations of epinephrine $\left(10^{-8}, 10^{-7}, 10^{-6} \mathrm{~g} / \mathrm{L}\right)(\mathrm{P}<0.05$, respectively). Moreover, renalase secretion presented a positive association with epinephrine concentration, as shown in Fig.1A. Renalase mRNA levels were elevated at $6 \mathrm{hr}$ and $12 \mathrm{hr}$ with the stimulation of epinephrine ( $\mathrm{P}<0.05$ respectively). After $24 \mathrm{hr}$ treatment with epinephrine, the renalase mRNA of HK2 cells was maintained at higher levels compared to control, but exhibited a downward trend, as shown in Fig.1B and 1C. The time course showed that renalase secretion increased quickly after $6 \mathrm{hr}$ treatment with epinephrine (Fig.1E).

Epinephrine-evoked renalase expression was inhibited by $\alpha$-adrenoceptor blocker

Renalase protein levels in the supernatant of HK2 cells treated with epinephrine $\left(10^{-}\right.$ $\left.{ }^{7} \mathrm{~g} / \mathrm{L}\right)$ were attenuated by phentolamine $(1.0 \mu \mathrm{mol} / \mathrm{L})$ at $24 \mathrm{hr}$ as shown in Fig.2A. It can be observed that epinephrine $\left(10^{-7} \mathrm{~g} / \mathrm{L}\right)$ raised renanalse mRNA levels at $6 \mathrm{~h}$ compared with the control $(\mathrm{P}<0.01)$. However, pretreatment with phentolamine $(1.0 \mu \mathrm{mol} / \mathrm{L})$ suppressed epinephrine-stimulated renalase expression in HK2 cells $(\mathrm{P}<0.05)$, as represented in Fig.2B. These results suggest stimulation of $\alpha$-adrenoceptor may be involved in the epinephrineevoked renalase expression.

Epinephrine-evoked renalase expression is mediated by $N F \kappa B$

It was found that Phospho-IKB $\alpha$ increased significantly in HK2 cells treated with epinephrine $\left(10^{-7} \mathrm{~g} / \mathrm{L}\right)$ at $15 \mathrm{~min}$ and was inhibited by TPCK $(45 \mu \mathrm{mol} / \mathrm{L})$ (Fig.3A). The elevations of renalase mRNA resulting from epinephrine stimulation were suppressed by TPCK $(45 \mu \mathrm{mol} / \mathrm{L})($ Fig.3B) $(\mathrm{P}<0.05)$. Thus, epinephrine-evoked renalase expression might be mediated by $\mathrm{NF} \kappa \mathrm{B}$ pathways.

\section{Discussion}

Renalase is a recently discovered monoamine oxidase from the kidney that degrades catecholamines $[1,11,12]$. Renal proximal tubular epithelial cells are able to secrete renalase, but podocytes or mesangial cells are not [7]. Epinephrine infusion increased renalase levels, but the pathways mediating the expression of renalase are still unclear [13].

The present study demonstrated that renalase expression could be induced by epinephrine in renal proximal tubular epithelial cells. It was found that renalase gene expression was much higher at $6 \mathrm{hr}$ after incubation with epinephrine than that in control 


\section{Kidney \\ Blood Pressure \\ Research}

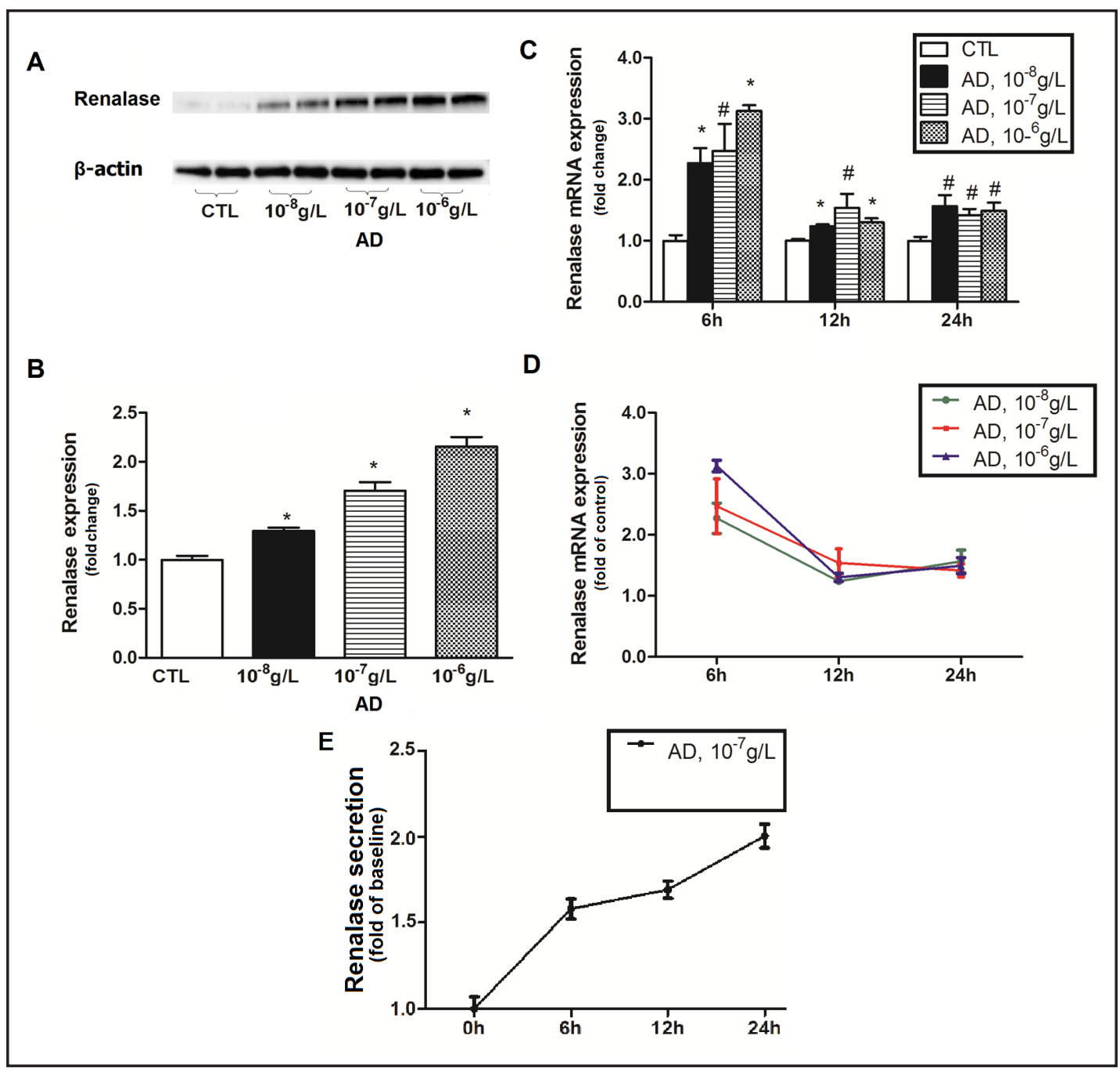

Fig. 1. Epinephrine induced renalase expression. Renalase protein levels increased significantly at $24 \mathrm{hr}$ in the supernatants of HK2 cells incubated with three different concentrations of epinephrine $\left(10^{-8}, 10^{-7}, 10^{-6}\right.$ $\mathrm{g} / \mathrm{L}$ ) (vs control, $\mathrm{P}<0.01$ respectively) (A and B). Renalase mRNA levels elevated at $6 \mathrm{hr}, 12 \mathrm{hr}$ and $24 \mathrm{hr}$ with the stimulation of epinephrine $(\mathrm{P}<0.01$ and $\mathrm{P}<0.05$ respectively) (B). Levels of renalase mRNA presented a downward trend with the epinephrine's stimulation time ( $C$ and $D)(n=6)$. Fig.1E showed the time course of renalase secretion with epinephrine stimulation using Western blot $\left(10^{-7} \mathrm{~g} / \mathrm{L}, \mathrm{n}=6\right)$. CTL, control; AD, epinephrine; *vs CTL, P<0.01; \#vs CTL, P<0.05.

assessed by quantitative PCR. The elevation of renalase mRNA was maintained until $24 \mathrm{hr}$ after treated with epinephrine. The increased secretory renalase protein was detected by Western blot after epinephrine stimulation (Fig. 1). The results were consistent with previous reports about renalase expression in vivo $[8,13]$. The results did not tell how much of the detected renalase protein was from the stored renalase inside the cells or newly synthesized. It is necessary to investigate the time-course of renalase expression in more detail in the future.

Also, this study showed that renalase expression evoked by epinephrine was blocked by phentolamine, an $\alpha$-adrenoceptor antagonist (Fig. 2). As an organ innervated by sympathetic nerves, the kidney has abundant $\alpha$-adrenoceptors on the proximal tubular epithelial cells that are related to metabolism of water and salt. The renal sympathetic nerve has a crucial role in 


\section{Kidney \\ Blood Pressure \\ Research}

A
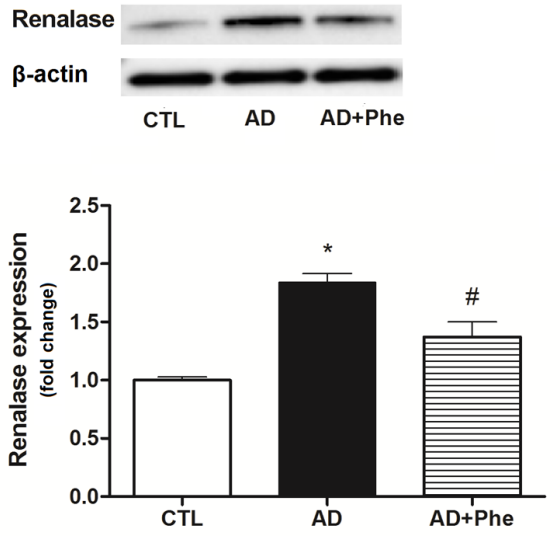

B

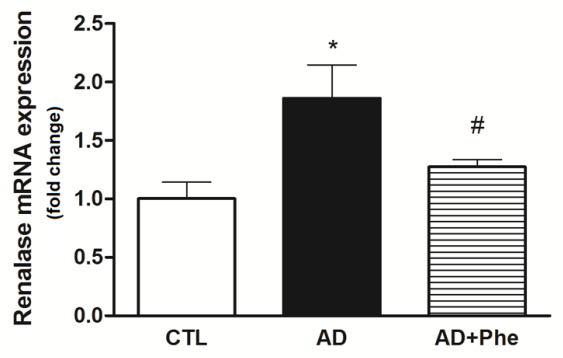

Fig. 2. Phentolamine attenuated epinephrine-evoked renalase expression. Epinephrine-induced $\left(10^{-7} \mathrm{~g} / \mathrm{L}\right)$ renalase protein levels in the supernatants of HK2 cells were attenuated by phentolamine $(1.0 \mu \mathrm{mol} / \mathrm{L})$ at $24 \mathrm{hr}$ (vs control, $\mathrm{P}<0.01)(\mathrm{n}=6)(\mathrm{A})$. Renalase mRNAs were reduced by pre-conditioned phentolamine $(1.0 \mu \mathrm{mol} / \mathrm{L})(\mathrm{n}=6, \mathrm{P}<0.01)(\mathrm{B}) . \mathrm{CTL}$, control; AD, epinephrine; Phe, phentolamine; *vs CTL, $\mathrm{P}<0.01$; \#vs AD, $\mathrm{P}<0.05$.

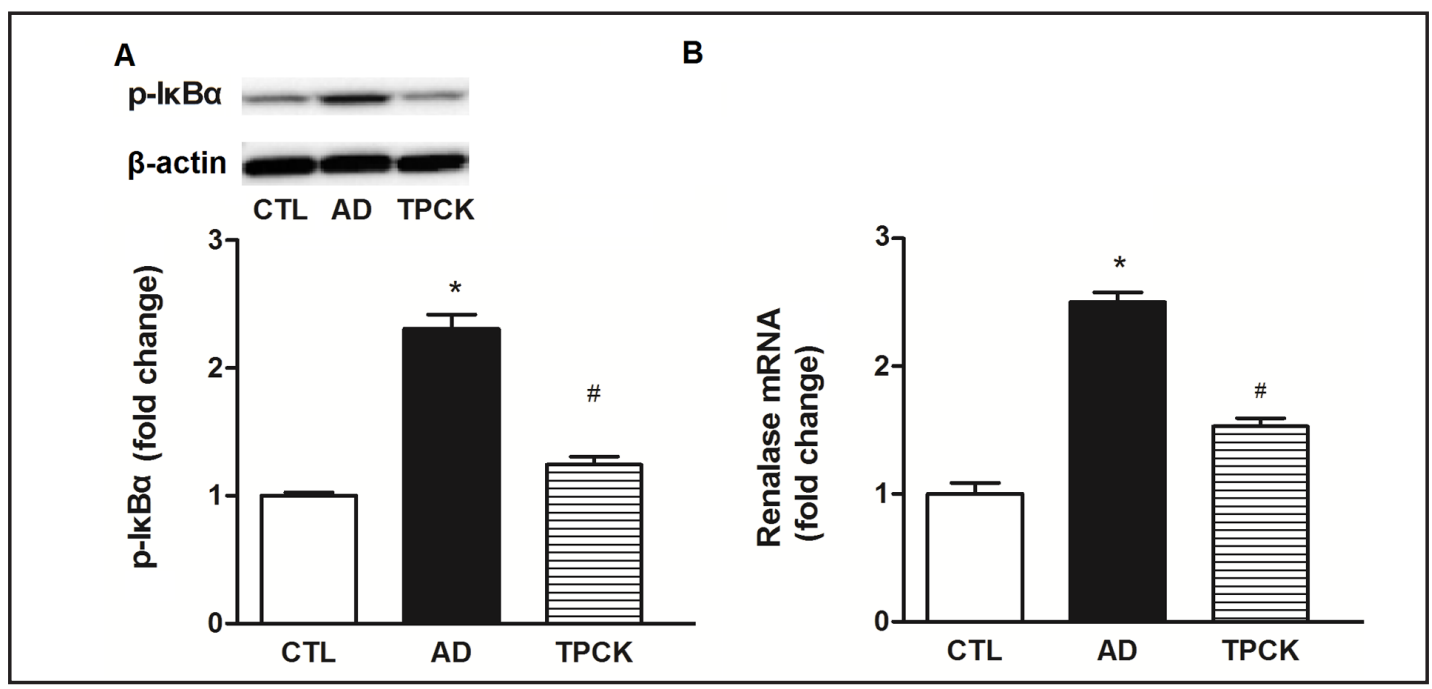

Fig. 3. TPCK supressed epinephrine-evoked renalase expression. Phospho-IкB $\alpha$ increased significantly in HK2 cells treated with epinephrine $\left(10^{-7} \mathrm{~g} / \mathrm{L}\right)$ at $15 \mathrm{~min}(\mathrm{~A})(\mathrm{n}=6)$. Renalase mRNAs were attenuated by TPCK $(45 \mu \mathrm{mol} / \mathrm{L})$ at $6 \mathrm{hr}$ after treatment with epinephrine $(\mathrm{P}<0.05)(\mathrm{B})(\mathrm{n}=6)$. CTL, control; TPCK, tosyl phenylalanyl chloromethyl ketone; AD, epinephrine; *vs CTL, $\mathrm{P}<0.01$; \#vs AD, $\mathrm{P}<0.05$.

regulating arterial blood pressure and renal denervation is becoming an effective treatment for refractory hypertension [14-16]. It could be speculated that $\alpha$-adrenoceptors may play a key role in epinephrine-induced renalase expression. Whether $\alpha 1$ or $\alpha 2$ adrenoceptors are involved in the renalase expression needs further investigation. Very recently Wang S. et al. reported that renalase expression was regulated by D5 dopamine receptors in rat renal proximal tubular cells treated with dopamine [17]. This demonstrated that renalase regulation is quite complex. More investigations regarding the regulation of renalase is needed. 


\section{Kidney \\ Blood Pressure Research}

Kidney Blood Press Res 2014;39:252-259

\begin{tabular}{l|l}
\hline DOI: $10.1159 / 000355802$ & (C) 2014 S. Karger AG, Basel
\end{tabular}

Publisned ontrne: August 06, 2014

www.karger.com/kbr

Wang/Cai/Zhao/Xing/Li/Wang: Epinephrine Evokes Renalase via $\alpha$-Adrenoceptor/NFKB Pathways

In addition, phospho-IкB $\alpha$ increased significantly in HK2 cells treated with epinephrine, which confirmed that NFKB was activated by epinephrine. These results manifested that epinephrine-induced renalase expression was blunted when NFKB was inhibited with TPCK. It was indicated that the transcription factor $\mathrm{NF} \kappa \mathrm{B}$ plays a pivotal role in regulating renalase expression in proximal tubular epithelial cells.

Accumulating evidence indicates that both $\alpha$ and $\beta$ adrenergic receptors (AR) play an active role in the NF-kB pathway. It is reported that $\alpha 1$-ARs stimulated IL- 6 expression and secretion through p38 MAPK and NF-kappaB pathways [18]. Tan KS. et al demonstrated that $\beta 2$ AR activation stimulated pro-inflammatory cytokine production in macrophages via PKAand NF-kB-independent mechanisms [19]. $\beta$-AR agonists may also increase the production

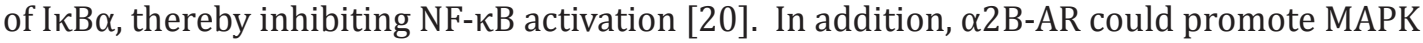
activation in a clone of the renal tubular cell line [21]. In brief, AR pathways and their biological functions are complicated. Which subtype of AR involved in renalase secretion should be further invesitigated.

It was concluded that epinephrine stimulated renalase expression in proximal tubular epithelial cells may be via $\alpha$-adrenoceptor/NFKB pathways. This finding has not been reported before and will pave the way to explore the mechanisms mediating renalase secretion in more detail.

Furthermore, a previous study by Jiang W. et al. demonstrated that renal denervation increased renalase levels in plasma and kidney [22]. This study exhibited phentolamine may inhibit renalase expression, which might lead to increase blood pressure. This seems contradictory. Usually the modulations of biological molecules are much more intricate in vivo than in vitro. Indeed, the regulation of blood pressure is a complicated field. Another limitation to this study is that the activity of renalase was not determined.

\section{Conclusion}

The discovery of renalase is a great progression that may reveal novel mechanisms and explanations to hypertention and high risk of cardiovascular complications in patients with CKD [23-27]. Studies surrounding renalase provide new evidences for the crucial role of the kidney in blood pressure regulation. More in-depth research is finding that renalase is involved in not only hypertension but also in heart failure, stroke, diabetes, and insulin resistance [28-31]. Renalase may be a valuable and effective drug for hypertension and CKD [32]. It is important to better understand the pathways affecting renalase expression. Upregulation of renalase might be another novel therapeutic method in the future.

\section{Disclosure Statement}

The authors of this manuscript state that they do not have any conflict of interests and nothing to disclose.

\section{Acknowledgements}

This work was sponsored by the National Natural Science Foundation of China (81100528 and 81270824), the New-100 talent Plan of Shanghai Jiao Tong University School of Medicine, and Shanghai talents development fund. 


\section{Kidney \\ Blood Pressure Research}

\section{References}

1 Xu J, Li G, Wang P, Velazquez H, Yao X, Li Y, Wu Y, Peixoto A, Crowley S, Desir GV: Renalase is a novel, soluble monoamine oxidase that regulates cardiac function and blood pressure. J Clin Invest 2005;115:1275-1280.

-2 Xu J, Desir GV: Renalase, a new renal hormone: its role in health and disease. Curr Opin Nephrol Hypertens 2007;16:373-378.

3 Desir GV, Peixoto AJ: Renalase in hypertension and kidney disease. Nephrol Dial Transplant 2014;29:22-28.

4 Desir GV, Tang L, Wang P, Li G, Sampaio-Maia B, Quelhas-Santos J, Pestana M, Velazquez H: Renalase lowers ambulatory blood pressure by metabolizing circulating adrenaline. J Am Heart Assoc 2012;1:e002634.

5 Desir GV, Wang L, Peixoto AJ: Human renalase: a review of its biology, function, and implications for hypertension. J Am Soc Hypertens 2012;6:417-426.

6 Wu Y, Xu J, Velazquez H, Wang P, Li G, Liu D, Sampaio-Maia B, Quelhas-Santos J, Russell K, Russell R, Flavell RA, Pestana M, Giordano F, Desir GV: Renalase deficiency aggravates ischemic myocardial damage. Kidney Int 2011;79:853-860.

7 Wang F, Xing T, Li J, Bai M, Hu R, Zhao Z, Tian S, Zhang Z, Wang N: Renalase's expression and distribution in renal tissue and cells. PLoS One 2012;7:e46442.

8 Gu R, Lu W, Xie J, Bai J, Xu B: Renalase deficiency in heart failure model of rats--a potential mechanism underlying circulating norepinephrine accumulation. PLoS One 2011;6:e14633.

9 Wang F, Zhao Q, Xing T, Li J, Wang N: Renalase-specific polyclonal antibody and its application in the detection of renalase's expression. Hybridoma (Larchmt) 2012;31:378-381.

10 Wang F, Wang NS, Xing T, Cao Y, Xiang HY: The cloning and expression of renalase and the preparation of its monoclonal antibody. J Shanghai Jiaotong Univ Sci 2009;14:4.

11 Desir G: Novel insights into the physiology of renalase and its role in hypertension and heart disease. Pediatr Nephrol 2012;27:719-725.

12 Desir GV: Regulation of blood pressure and cardiovascular function by renalase. Kidney Int 2009;76:366370.

13 Li G, Xu J, Wang P, Velazquez H, Li Y, Wu Y, Desir GV: Catecholamines regulate the activity, secretion, and synthesis of renalase. Circulation 2008;117:1277-1282.

14 Judd E, Calhoun DA: Apparent and true resistant hypertension: definition, prevalence and outcomes. J Hum Hypertens 2014;28:463-468.

15 Leong KT, Walton A, Krum H: Renal sympathetic denervation for the treatment of refractory hypertension. Annu Rev Med 2014;65:349-365.

16 Eleid MF, Schwartz GL, Gulati R: Renal denervation for hypertension. Curr Probl Cardiol 2014;39:35-51.

17 Wang S, Lu X, Yang J, Wang H, Chen C, Han Y, Ren H, Zheng S, He D, Zhou L, Asico LD, Wang WE, Jose PA, Zeng C: Regulation of renalase expression by D5 dopamine receptors in rat renal proximal tubule cells. Am J Physiol Renal Physiol 2014;306:F588-F596.

18 Perez DM, Papay RS, Shi T: alpha1-Adrenergic receptor stimulates interleukin- 6 expression and secretion through both mRNA stability and transcriptional regulation: involvement of p38 mitogen-activated protein kinase and nuclear factor-kappaB. Mol Pharmacol 2009;76:144-152.

19 Tan KS, Nackley AG, Satterfield K, Maixner W, Diatchenko L, Flood PM: Beta2 adrenergic receptor activation stimulates pro-inflammatory cytokine production in macrophages via PKA- and NF-kappaB-independent mechanisms. Cell Signal 2007;19:251-260.

20 Ye RD: Regulation of nuclear factor kappaB activation by G-protein-coupled receptors. J Leukoc Biol 2001;70:839-848.

21 Cussac D, Schaak S, Denis C, Paris H: alpha 2B-adrenergic receptor activates MAPK via a pathway involving arachidonic acid metabolism, matrix metalloproteinases, and epidermal growth factor receptor transactivation. J Biol Chem 2002;277:19882-19888.

22 Jiang W, Guo Y, Tan L, Tang X, Yang Q, Yang K: Impact of renal denervation on renalase expression in adult rats with spontaneous hypertension. Exp Ther Med 2012;4:493-496.

23 Desir GV: Renalase is a novel renal hormone that regulates cardiovascular function. J Am Soc Hypertens 2007;1:99-103.

-24 Lee HT, Kim JY, Kim M, Wang P, Tang L, Baroni S, D'Agati VD, Desir GV: Renalase protects against ischemic AKI. J Am Soc Nephrol 2013;24:445-455. 


\section{Kidney \\ Blood Pressure Research}

25 Hennebry SC, Eikelis N, Socratous F, Desir G, Lambert G, Schlaich M: Renalase, a novel soluble FADdependent protein, is synthesized in the brain and peripheral nerves. Mol Psychiatry 2010;15:234-236. Paulis L, Unger T: Novel therapeutic targets for hypertension. Nat Rev Cardiol 2010;7:431-441.

27 Unger T, Paulis L, Sica DA: Therapeutic perspectives in hypertension: novel means for renin-angiotensinaldosterone system modulation and emerging device-based approaches. Eur Heart J 2011;32:2739-2747.

28 Farzaneh-Far R, Desir GV, Na B, Schiller NB, Whooley MA: A functional polymorphism in renalase (Glu37Asp) is associated with cardiac hypertrophy, dysfunction, and ischemia: data from the heart and soul study. PLoS One 2010;5:e13496.

29 Stec A, Semczuk A, Furmaga J, Ksiazek A, Buraczynska M: Polymorphism of the renalase gene in end-stage renal disease patients affected by hypertension. Nephrol Dial Transplant 2012;27:4162-4166.

30 Wang F, Huang B, Li J, Liu L, Wang N: Renalase might be associated with hypertension and insulin resistance in Type 2 diabetes. Ren Fail 2014;36:552-556.

31 Wang F, Li J, Xing T, Xie Y, Wang N: Serum renalase is related to catecholamine levels and renal function. Clin Exp Nephrol 2014, DOI 10.1007/s10157-014-0951-8

-32 Desir GV: Role of renalase in the regulation of blood pressure and the renal dopamine system. Curr Opin Nephrol Hypertens 2011;20:31-36. 